\section{Relationship of Seasonal Changes in Endogenous Plant Hormones and Alternate Bearing of Olive Trees}

\author{
I. Baktir, ${ }^{1}$ S. Ulger, ${ }^{2}$ and L. Kaynak ${ }^{1}$ \\ Department of Horticulture, University of Akdeniz, Antalya, Turkey
}

David G. Himelrick ${ }^{3}$

Department of Horticulture, Louisiana State University, Baton Rouge, LA 70803-2120

\begin{abstract}
Additional index words. cytokinin, gibberellin, auxin, abscisic acid, IAA, GA, ABA, Olea europaea
\end{abstract}

\begin{abstract}
Changes in hormone concentrations in leaf, node, shoot tip, and fruit samples of three Turkish olive (Olea europaea L.) cultivars ('Gemlik', 'Memecik', and 'Tavsan Yuregi') were monitored at monthly intervals over two successive years of the alternatebearing cycle. Concentrations of abscisic acid (ABA), indole acetic acid (IAA), gibberellic acid-like substances (GA), and kinetin-like cytokinin were determined and their relationship to flower bud formation were examined during "on" and "off" years. Results showed significant differences in IAA, ABA, GA -like, and kinetin-like cytokinins between "on" and "off" cropping years in various tissues of olive trees. Relative balances between $\mathrm{GA}_{3}$-like and $A B A$ concentrations of tissues appears to exhibit evidence of being a key regulator of floral development and alternate bearing.
\end{abstract}

Olive is native to the Mediterranean basin, where about $97 \%$ of the world's olive crop is produced. Although olive trees are well adapted to the region, alternate bearing is one of the major cultural problems and economic drawbacks. Alternate bearing causes severe economic losses in many of the important olive cultivars. Typical yield loss in commercial plantings in the "off" year is nearly $50 \%$. In the case of Turkey, "on" year production averages about 1.8 million tons while "off" year production only reaches 0.9 to 1.0 million tons (Agricultural Structure and Production, 1989).

Cultural and environmental factors, such as pruning, drought, inadequate chilling, and light intensity, may influence flower bud formation and contribute to alternate bearing (Hartmann, 1953; Lavee, 1985). Endogenous phytohormones are key factors controlling alternate-bearing physiology. Hartmann et al. (1967) measured both endogenous inhibitors and promoters in olive leaves and buds. Lavee (1985) found more chlorogenic acid in bearing than in nonbearing olive trees. The assumption that chlorogenic acid induced flower bud formation was not supported when application of chlorogenic acid decreased yield. Hartmann et al. (1967) found no difference in auxin concentrations of differentiating and nondifferentiating olive buds, while Epstein (1981) showed considerably higher levels of bound IAA in leaves of nondifferentiated

\footnotetext{
Received for publication 12 Aug. 2002. Accepted for publication 27 May 2003. This research was supported by The Turkish Scientific and Technical Research Council.

${ }^{1}$ Professor.

${ }^{2}$ Associate professor.

${ }^{3}$ Professor and head.
}

plants. Gibberellins strongly inhibit flowering, although the mechanism by which this occurs is not fully understood (Palese et al., 2002). Alternate bearing in olives results in fewer floral buds being produced in the "on" year trees carrying a heavy crop load than in subsequent "off" year with trees carrying a light fruit load.

The present study reports the pattern of abscisic acid (ABA), gibberellic acid-like substances $\left(\mathrm{GA}_{3}\right)$, indole acetic acid (IAA), and kinetin-like cytokinins in the tissues of alternate-bearing olive trees.

\section{Materials and Methods}

In this experiment, mature 30-year-old 'Gemlik', 'Memecik', and 'Tavsan Yuregi' olive trees growing at the Murat Pasha Foundation Orchard in Antalya, Turkey, were used. Three-tree plots of each cultivar were replicated three times in a randomized block design. Hormonal analysis was conducted on nodes, shoot tips, and leaves of the current-season growth along with fruit samples. Samples consisted of $10 \mathrm{~g}$ fresh weight of each plant part selected from the periphery of the tree at a height of $1.5 \mathrm{~m}$ on each of the four cardinal aspects of the tree. Sampling began in Nov. 1994 and continued at monthly intervals until Oct. 1996. Analysis of ABA, GA-like substances, IAA, and kinetin-like cytokinins was determined according to Rivier and Crozier (1987). Samples were homogenized in cold $70 \%$ methanol at room temperature, and were temporarily stored at $7{ }^{\circ} \mathrm{C}$. The extracts were filtered through Whatman No. 5 filter paper and the supernatant was rehomogenized with the same solution, and the extracts were combined. The methanol phase was reduced to the aqueous phase under reduced pressure on a rotary evaporator at 40
${ }^{\circ} \mathrm{C}$. The aqueous residue was adjusted to $\mathrm{pH} 8.5$ with $1 \mathrm{~N} \mathrm{NaOH}$, and extracted three times with ethyl acetate; the ethyl acetate phase was then discarded. The aqueous phase was adjusted to $\mathrm{pH} 2.5$ with $1 \mathrm{~N} \mathrm{HCl}$ and extracted 3 times with diethyl ether. The ethyl ether phase was reduced under vacuum. The crude extract was dissolved in $1 \mathrm{~mL}$ methanol. Samples of crude extract $(100 \mu \mathrm{L})$ were applied to TLC plates (Merc Silica Gel 60 F254) and then developed in an 84 misopropyl alcohol : 8 ammonia : 8 water (v/v) solvent. Spots detected under an ultraviolet (UV) lamp were scraped from the plates, dissolved in $1 \mathrm{~mL}$ HPLC grade methanol, and filtered through $45 \mu$ micropore filters. High-pressure liquid chromatography (HPLC) analysis of the phytohormones was performed by reversed-phase HPLC on a Varian Model 9050 (Walnut Creek, Calif.) equipped with a variable wavelength UV detector and autosampler. Separation and determination were conducted using a nucleosil $\mathrm{C}_{18}(4.6 \times 150$ $\mathrm{mm}$ i.d.) column. Samples were run at $25{ }^{\circ} \mathrm{C}$ column temperatures. Columns were eluted with $30 \%$ methanol (adjusted to $\mathrm{pH} 3.0$ with $0.1 \mathrm{M} \mathrm{H}_{3} \mathrm{PO}_{4}$ ) for GA, 55\% methanol in 0.1 $\mathrm{M}$ acetic acid for ABA, 35\% methanol in 1\% acetic acid for ABA, 35\% methanol in 1\% acetic acid for IAA, and 35\% methanol for kinetin-like cytokinin. Detection was by a variable wavelength UV detector at 208, 265, 280 , and $254 \mathrm{~nm}$ for GA-like substances, ABA, IAA, and kinetin-like cytokinin, respectively. Twenty milliliters of methanol solution was injected into the analytical columns using an autosampler. The flow rate was $1 \mathrm{~mL} \cdot \mathrm{min}^{-1}$. Phytohormone concentrations $\left(\mu \mathrm{g} \cdot \mathrm{g}^{-1}\right.$ fresh weight) were automatically calculated from peak area software using authentic standards run with the samples (Sigma Chemical, St. Louis).

\section{Results and Discussion}

The physiological process leading to spring flowering begins in the preceding summer as environmental factors initiate the induction processes. Flower bud induction in olive may occur as early as July or $\approx 6$ weeks after full bloom. Microscopic examination revealed evidence of floral initiation by November but the full development of all flower parts did not occur until March (Martin et al., 1994). Dokuzoguz and Mendilcioglu (1976) indicated that the initiation period started in winter months in the Mediterranean region.

In his review of olive fruit set and development, Lavee (1986) highlighted the report concluding that levels of auxins and cytokinins in olive tissues were considerably lower than those of other fruit trees. In the present experiment our results indicated low or undetectable levels of phytohormones in various tissues at many times during the year. In general, $\mathrm{GA}_{3}$-like substance levels in leaf, node, and shoot tip samples were higher in the "on" year in comparison to levels in the "off" year. GA levels started to rise at fruit set and these levels were maintained until harvest in the "on" year. High $\mathrm{GA}_{3}$-like concentrations in midsummer (embryo development period) 
Table 1. GA-like concentrations ( $\mu \mathrm{g} \cdot \mathrm{g}^{-1}$ fresh weight) in leaf, node, shoot tip, and fruit of 'Gemlik', 'Memecik', and 'Tav an Yüre i' olive cultivars in "on" and "off" years of the alternate-bearing cycle.

\begin{tabular}{|c|c|c|c|c|c|c|c|c|c|c|c|c|c|c|}
\hline \multirow[b]{2}{*}{ Cultivar } & \multirow{2}{*}{$\begin{array}{l}\text { Plant } \\
\text { part }\end{array}$} & \multirow{2}{*}{$\begin{array}{c}\text { On/off } \\
\text { year }\end{array}$} & \multicolumn{12}{|c|}{ Month } \\
\hline & & & Nov. & Dec. & Jan. & Feb. & Mar. & Apr. & May & June & July & Aug. & Sept. & Oct. \\
\hline \multirow[t]{7}{*}{ Memecik } & \multirow[t]{2}{*}{ Leaf } & On & 0.56 & 2.28 & 0.48 & 0.74 & 1.17 & 2.60 & 0.43 & 0.50 & 0.09 & 0.30 & 0.33 & 0.67 \\
\hline & & Off & 0.36 & 0.10 & 0.68 & 0.31 & 0.40 & 1.20 & 0.27 & 0.32 & 1.10 & 0.42 & 0.69 & 0.92 \\
\hline & \multirow[t]{2}{*}{ Node } & On & 1.74 & 2.12 & 2.10 & 0.68 & 0.20 & 0.23 & 0.68 & 0.03 & 0.12 & 0.02 & 0.24 & 0.10 \\
\hline & & Off & 0.36 & 0.02 & 0.51 & 0.04 & 0.02 & 0.64 & 0.14 & 0.78 & 1.10 & 0.70 & 1.53 & 1.91 \\
\hline & \multirow[t]{2}{*}{ Shoot tip } & On & 1.38 & 3.39 & 0.95 & 2.14 & 0.54 & 0.36 & 0.04 & 0.14 & 0.11 & 0.05 & 0.14 & 0.10 \\
\hline & & Off & 0.19 & 0.07 & 0.08 & 0.84 & 0.09 & 0.10 & 0.70 & 0.22 & 0.08 & 0.56 & 1.12 & 0.10 \\
\hline & Fruit & On & 0.83 & 0.15 & 0.00 & 0.00 & 0.00 & 0.00 & 1.28 & 1.41 & 1.18 & 0.89 & 0.36 & 2.36 \\
\hline \multirow{7}{*}{$\begin{array}{l}\text { Tavsan } \\
\text { Yuregi }\end{array}$} & \multirow[t]{2}{*}{ Leaf } & On & 0.20 & 3.60 & 1.14 & 1.17 & 1.20 & 0.86 & 0.71 & 0.21 & 1.48 & 1.20 & 0.10 & 0.84 \\
\hline & & Off & 0.01 & 0.35 & 0.29 & 0.12 & 0.10 & 0.74 & 0.18 & 0.40 & 0.38 & 1.02 & 0.11 & 0.65 \\
\hline & \multirow[t]{2}{*}{ Node } & On & 1.76 & 3.37 & 1.18 & 0.18 & 1.18 & 0.36 & 0.56 & 0.02 & 0.31 & 0.04 & 0.11 & 0.09 \\
\hline & & Off & 0.11 & 0.24 & 0.20 & 0.13 & 0.04 & 0.22 & 0.17 & 0.62 & 0.81 & 1.34 & 2.10 & 1.81 \\
\hline & \multirow[t]{2}{*}{ Shoot tip } & On & 0.70 & 0.92 & 0.30 & 0.40 & 0.26 & 0.20 & 0.07 & 0.02 & 0.02 & 0.04 & 0.22 & 0.24 \\
\hline & & Off & 0.01 & 0.02 & 0.06 & 0.06 & 0.04 & 0.36 & 0.91 & 0.09 & 0.16 & 0.51 & 0.24 & 0.58 \\
\hline & Fruit & On & 0.40 & 0.00 & 0.00 & 0.00 & 0.00 & 0.00 & 0.45 & 1.96 & 1.16 & 1.23 & 0.98 & 0.68 \\
\hline \multirow[t]{7}{*}{ Gemlik } & \multirow[t]{2}{*}{ Leaf } & On & 0.39 & 4.44 & 3.77 & 2.16 & 2.47 & 0.03 & 1.42 & 0.16 & 0.22 & 0.40 & 0.21 & 0.95 \\
\hline & & Off & 1.04 & 0.28 & 0.18 & 0.50 & 0.13 & 0.87 & 0.69 & 0.94 & 1.50 & 0.73 & 0.22 & 0.02 \\
\hline & \multirow[t]{2}{*}{ Node } & On & 1.54 & 1.75 & 1.04 & 0.09 & 0.34 & 0.40 & 0.30 & 0.02 & 0.09 & 0.03 & 0.22 & 0.03 \\
\hline & & Off & 0.44 & 0.09 & 0.14 & 0.10 & 0.06 & 0.38 & 0.31 & 0.81 & 0.40 & 1.38 & 1.18 & 0.42 \\
\hline & \multirow[t]{2}{*}{ Shoot tip } & On & 0.81 & 0.23 & 0.20 & 0.09 & 0.33 & 0.46 & 0.90 & 0.19 & 0.09 & 0.03 & 0.09 & 0.36 \\
\hline & & Off & 0.25 & 0.08 & 0.04 & 0.10 & 0.06 & 0.45 & 0.46 & 0.12 & 0.06 & 0.17 & 0.10 & 0.64 \\
\hline & Fruit & On & 0.68 & 0.00 & 0.00 & 0.00 & 0.00 & 0.00 & 0.68 & 2.11 & 0.96 & 0.97 & 0.48 & 0.55 \\
\hline
\end{tabular}

Table 2. ABA concentrations ( $\mu \mathrm{g} \cdot \mathrm{g}^{-1}$ fresh weight) in leaf, node, shoot tip, and fruit of Gemlik, 'Memecik', and 'Tav an Yüre i' olive cultivars in “on” and "off” years of the alternate-bearing cycle.

\begin{tabular}{|c|c|c|c|c|c|c|c|c|c|c|c|c|c|c|}
\hline \multirow[b]{2}{*}{ Cultivar } & \multirow{2}{*}{$\begin{array}{l}\text { Plant } \\
\text { part }\end{array}$} & \multirow{2}{*}{$\begin{array}{c}\text { On/off } \\
\text { year }\end{array}$} & \multicolumn{12}{|c|}{ Month } \\
\hline & & & Nov. & Dec. & Jan. & Feb. & Mar. & Apr. & May & June & July & Aug. & Sept. & Oct. \\
\hline \multirow[t]{7}{*}{ Memecik } & \multirow[t]{2}{*}{ Leaf } & On & 0.35 & 0.02 & 0.22 & 0.03 & 0.12 & 0.13 & 0.32 & 1.24 & 1.45 & 0.46 & 2.26 & 0.30 \\
\hline & & Off & 0.43 & 0.25 & 0.03 & 0.31 & 0.94 & 0.21 & 1.35 & 0.43 & 0.60 & 0.59 & 1.95 & 1.50 \\
\hline & \multirow[t]{2}{*}{ Node } & On & 0.33 & 1.44 & 0.69 & 0.12 & 0.09 & 0.05 & 0.29 & 0.36 & 0.48 & 0.43 & 1.36 & 0.30 \\
\hline & & Off & 0.41 & 0.22 & 0.80 & 0.16 & 0.32 & 0.27 & 0.32 & 0.36 & 0.37 & 0.50 & 0.88 & 1.33 \\
\hline & \multirow[t]{2}{*}{ Shoot tip } & On & 0.66 & 0.45 & 0.18 & 1.30 & 0.10 & 0.19 & 0.21 & 0.15 & 0.11 & 0.10 & 0.27 & 0.02 \\
\hline & & Off & 0.07 & 0.18 & 0.04 & 0.10 & 0.07 & 0.10 & 0.20 & 0.22 & 0.34 & 0.18 & 0.97 & 0.17 \\
\hline & Fruit & On & 0.36 & 0.00 & 0.00 & 0.00 & 0.00 & 0.00 & 0.28 & 0.26 & 0.32 & 0.50 & 0.77 & 1.17 \\
\hline Tavsan & Leaf & On & 0.37 & 1.10 & 1.76 & 0.81 & 0.08 & 0.10 & 0.37 & 0.86 & 1.16 & 0.57 & 2.33 & 0.21 \\
\hline \multirow[t]{6}{*}{ Yuregi } & & Off & 0.36 & 0.41 & 0.05 & 0.08 & 0.29 & 0.15 & 0.35 & 0.63 & 0.27 & 0.07 & 1.44 & 1.29 \\
\hline & \multirow{2}{*}{ Node } & On & 0.40 & 1.62 & 0.39 & 0.17 & 0.14 & 0.11 & 0.21 & 0.08 & 0.51 & 0.12 & 1.76 & 0.25 \\
\hline & & Off & 0.13 & 1.42 & 0.24 & 0.14 & 0.34 & 0.13 & 0.42 & 0.22 & 0.34 & 0.68 & 1.83 & 1.10 \\
\hline & \multirow[t]{2}{*}{ Shoot tip } & On & 0.60 & 0.64 & 1.77 & 0.04 & 0.18 & 0.06 & 0.20 & 0.08 & 0.06 & 0.09 & 0.72 & 0.26 \\
\hline & & Off & 0.06 & 0.05 & 0.14 & 0.25 & 0.14 & 0.21 & 0.16 & 0.14 & 0.61 & 0.27 & 0.34 & 0.10 \\
\hline & Fruit & On & 0.24 & 0.00 & 0.00 & 0.00 & 0.00 & 0.00 & 0.24 & 0.33 & 0.28 & 0.38 & 0.57 & 3.22 \\
\hline \multirow[t]{7}{*}{ Gemlik } & \multirow[t]{2}{*}{ Leaf } & On & 0.40 & 0.90 & 2.42 & 0.26 & 0.05 & 0.09 & 0.39 & 0.55 & 0.96 & 0.42 & 1.84 & 0.28 \\
\hline & & Off & 0.90 & 0.33 & 0.06 & 0.44 & 2.22 & 0.42 & 0.16 & 0.18 & 1.08 & 0.62 & 0.11 & 0.17 \\
\hline & \multirow[t]{2}{*}{ Node } & On & 0.38 & 0.97 & 0.79 & 0.07 & 0.10 & 0.23 & 0.17 & 0.33 & 0.16 & 0.23 & 0.47 & 0.14 \\
\hline & & Off & 0.09 & 0.32 & 0.96 & 0.30 & 0.36 & 0.19 & 0.38 & 0.31 & 0.18 & 0.69 & 0.32 & 0.25 \\
\hline & \multirow[t]{2}{*}{ Shoot tip } & On & 0.64 & 0.14 & 0.26 & 0.18 & 0.27 & 0.35 & 0.15 & 0.08 & 0.22 & 0.12 & 0.05 & 0.00 \\
\hline & & Off & 0.04 & 0.11 & 0.10 & 0.20 & 0.48 & 0.02 & 0.38 & 0.09 & 0.10 & 0.46 & 0.04 & 0.02 \\
\hline & Fruit & On & 0.52 & 0.00 & 0.00 & 0.00 & 0.00 & 0.00 & 0.19 & 0.44 & 0.53 & 0.57 & 0.68 & 1.23 \\
\hline
\end{tabular}

appeared to have a negative influence on generative bud development in favor of vegetative bud formation. Concentrations of $\mathrm{GA}_{3}$-like substance in all tissues in midsummer, fall, and winter prior to the "on" year were at the minimum levels in all three cultivars. However, $\mathrm{GA}_{3}$-like substance levels of all tissues sharply increased after fruit set. The highest $\mathrm{GA}_{3}$-like substance levels in the fruit-bearing period were found in fruits in June and July and then gradually decreased until December. $\mathrm{GA}_{3}$ levels also increased in leaves, nodes, and shoot tips during this time period, but the increases were not as substantial as those in fruit samples. Sequential determinations of gibberellins in developing olive fruits by Shulman and Lavee (1980) showed a gradual reduction in GA content during fruit development, with GA levels at full-black maturation being very low.
$\mathrm{GA}_{3}$-like substance levels in the leaf and node samples were found to be highest in December and January in the "on" year and then began to decrease until late spring, then increased again in midsummer (Table 1).

ABA concentrations in leaves of the three cultivars were irregular in both years, with ABA levels being higher in fall. Compared to summer and winter seasons, ABA concentrations in the nodes were almost the same in the fall and winter (between 0.30 and $1.90 \mu \mathrm{g} \cdot \mathrm{g}^{-1}$ ) and were at their minimal levels ( 0.08 to 0.7 $\left.\mu \mathrm{g} \cdot \mathrm{g}^{-1}\right)$ in spring and summer. This pattern is normal for inhibitors. The differences in ABA concentrations between nodes and shoot tips were not statistically significant in both "on" year and "off" year samples. In the nodes, ABA was lower in the spring and summer while levels were higher in fall and winter. ABA concentrations in fruits constantly increased from the time of fruit-set to ripening (Table 2). In contrast, Lavee (1986) indicated that ABA content in olive fruit decreases during ripening.

Kinetin-like cytokinin levels in leaves, nodes, and shoot tips in the "on" year were higher than in the "off" year. Shulman and Lavee (1976) showed that compared to most other fruits, cytokinin content in olive fruit increases with maturation. However, these levels in winter, spring, and summer were not statistically significant, while the levels were different in fall. Kinetin-like cytokinin in November and December in the "on" year produced detectable peaks (Table 3 ).

IAA was detectable only in the leaves and nodes $\left(0.25\right.$ to $\left.1.90 \mu \mathrm{g} \cdot \mathrm{g}^{-1}\right)$ of 'Memecik' and 'Tavsan Yuregi' cultivars during November 



in "on" and "off" years of the alternate-bearing cycle.

\begin{tabular}{|c|c|c|c|c|c|c|c|c|c|c|c|c|c|c|}
\hline \multirow[b]{2}{*}{ Cultivar } & \multirow{2}{*}{$\begin{array}{l}\text { Plant } \\
\text { part }\end{array}$} & \multirow{2}{*}{$\begin{array}{c}\text { On/off } \\
\text { year }\end{array}$} & \multicolumn{12}{|c|}{ Month } \\
\hline & & & Nov. & Dec. & Jan. & Feb. & Mar. & Apr. & May & June & July & Aug. & Sept. & Oct. \\
\hline \multirow[t]{7}{*}{ Memecik } & \multirow[t]{2}{*}{ Leaf } & On & 1.34 & 0.02 & 0.00 & 0.00 & 0.18 & 0.36 & 0.00 & 0.80 & 0.08 & 0.04 & 0.27 & 0.02 \\
\hline & & Off & 0.11 & 0.06 & 0.02 & 0.20 & 0.00 & 0.08 & 0.17 & 0.14 & 0.00 & 0.00 & 0.10 & 0.00 \\
\hline & \multirow[t]{2}{*}{ Node } & On & 1.59 & 0.20 & 0.48 & 0.24 & 1.12 & 0.27 & 0.00 & 0.50 & 0.19 & 0.48 & 0.11 & 0.00 \\
\hline & & Off & 0.12 & 0.00 & 0.19 & 0.33 & 0.00 & 0.00 & 0.03 & 0.13 & 0.20 & 0.20 & 0.37 & 0.00 \\
\hline & \multirow[t]{2}{*}{ Shoot tip } & On & 0.63 & 0.35 & 0.38 & 0.20 & 0.03 & 0.04 & 0.14 & 0.07 & 0.02 & 0.00 & 0.00 & 0.00 \\
\hline & & Off & 0.07 & 0.00 & 0.00 & 0.00 & 0.00 & 0.00 & 0.03 & 0.00 & 0.03 & 0.10 & 0.00 & 0.00 \\
\hline & Fruit & On & 0.56 & 0.00 & 0.00 & 0.00 & 0.00 & 0.00 & 0.07 & 0.04 & 0.15 & 0.64 & 0.24 & 0.00 \\
\hline \multirow{7}{*}{$\begin{array}{l}\text { Tavsan } \\
\text { Yuregi }\end{array}$} & \multirow[t]{2}{*}{ Leaf } & On & 0.30 & 0.94 & 0.22 & 0.10 & 0.00 & 0.00 & 0.14 & 0.08 & 0.00 & 0.07 & 0.05 & 0.06 \\
\hline & & Off & 0.17 & 0.00 & 0.00 & 0.03 & 0.11 & 0.16 & 0.00 & 0.03 & 0.03 & 0.06 & 0.03 & 0.00 \\
\hline & \multirow[t]{2}{*}{ Node } & On & 0.21 & 3.09 & 0.06 & 0.15 & 0.24 & 0.12 & 0.17 & 0.27 & 0.02 & 0.36 & 0.05 & 0.08 \\
\hline & & Off & 0.03 & 0.00 & 0.00 & 0.04 & 0.06 & 0.14 & 0.11 & 0.00 & 0.00 & 0.13 & 0.03 & 0.00 \\
\hline & \multirow[t]{2}{*}{ Shoot tip } & On & 0.89 & 0.29 & 0.00 & 0.08 & 0.00 & 0.00 & 0.13 & 0.13 & 0.03 & 0.04 & 0.00 & 0.03 \\
\hline & & Off & 0.05 & 0.06 & 0.00 & 0.00 & 0.02 & 0.03 & 0.11 & 0.00 & 0.00 & 0.00 & 0.00 & 0.00 \\
\hline & Fruit & On & 0.80 & 0.00 & 0.00 & 0.00 & 0.00 & 0.00 & 0.08 & 0.02 & 0.07 & 0.17 & 0.03 & 0.19 \\
\hline \multirow[t]{7}{*}{ Gemlik } & \multirow[t]{2}{*}{ Leaf } & On & 1.00 & 0.00 & 0.36 & 0.00 & 0.08 & 0.08 & 0.51 & 0.08 & 0.09 & 0.09 & 0.10 & 0.03 \\
\hline & & Off & 0.07 & 0.02 & 0.00 & 0.06 & 0.27 & 0.08 & 0.08 & 0.04 & 0.08 & 0.08 & 0.05 & 0.02 \\
\hline & \multirow[t]{2}{*}{ Node } & On & 0.93 & 0.51 & 0.67 & 0.00 & 0.11 & 0.28 & 0.04 & 0.04 & 0.16 & 0.19 & 0.15 & 0.20 \\
\hline & & Off & 0.06 & 0.00 & 0.00 & 0.13 & 0.16 & 0.20 & 0.37 & 0.02 & 0.10 & 0.12 & 0.14 & 0.16 \\
\hline & \multirow[t]{2}{*}{ Shoot tip } & On & 0.95 & 0.00 & 0.00 & 0.02 & 0.20 & 0.04 & 0.03 & 0.00 & 0.19 & 0.00 & 0.03 & 0.03 \\
\hline & & Off & 0.00 & 0.00 & 0.00 & 0.03 & 0.10 & 0.00 & 0.12 & 0.00 & 0.07 & 0.00 & 0.03 & 0.00 \\
\hline & Fruit & On & 0.68 & 0.00 & 0.00 & 0.00 & 0.00 & 0.00 & 0.16 & 0.00 & 0.12 & 0.06 & 0.14 & 0.07 \\
\hline
\end{tabular}

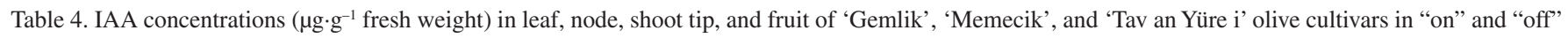
years of the alternate-bearing cycle.

\begin{tabular}{|c|c|c|c|c|c|c|c|c|c|c|c|c|c|c|}
\hline \multirow[b]{2}{*}{ Cultivar } & \multirow{2}{*}{$\begin{array}{l}\text { Plant } \\
\text { part }\end{array}$} & \multirow{2}{*}{$\begin{array}{c}\text { On/off } \\
\text { year }\end{array}$} & \multicolumn{12}{|c|}{ Month } \\
\hline & & & Nov. & Dec. & Jan. & Feb. & Mar. & Apr. & May & June & July & Aug. & Sept. & Oct. \\
\hline \multirow[t]{7}{*}{ Memecik } & \multirow[t]{2}{*}{ Leaf } & On & 0.00 & 1.34 & 0.00 & 0.06 & 0.00 & 0.00 & 0.00 & 0.00 & 0.00 & 0.14 & 0.07 & 0.29 \\
\hline & & Off & 0.00 & 0.60 & 0.00 & 0.00 & 0.00 & 0.00 & 0.00 & 0.00 & 0.00 & 0.00 & 0.03 & 0.00 \\
\hline & \multirow[t]{2}{*}{ Node } & On & 1.45 & 2.58 & 0.35 & 0.25 & 0.00 & 0.00 & 0.49 & 0.00 & 0.00 & 0.04 & 0.00 & 0.00 \\
\hline & & Off & 0.00 & 0.00 & 0.00 & 0.00 & 0.00 & 0.00 & 0.00 & 0.00 & 0.00 & 0.00 & 0.00 & 0.00 \\
\hline & \multirow[t]{2}{*}{ Shoot tip } & On & 1.19 & 0.00 & 0.20 & 0.00 & 0.00 & 0.00 & 0.00 & 0.00 & 1.60 & 0.00 & 0.00 & 0.00 \\
\hline & & Off & 0.00 & 0.00 & 0.00 & 0.00 & 0.00 & 0.00 & 0.00 & 0.00 & 0.00 & 0.00 & 0.00 & 0.00 \\
\hline & Fruit & On & 0.00 & 0.00 & 0.00 & 0.00 & 0.00 & 0.00 & 0.00 & 0.00 & 0.00 & 0.00 & 0.00 & 0.00 \\
\hline \multirow{7}{*}{$\begin{array}{l}\text { Tavsan } \\
\text { Yuregi }\end{array}$} & \multirow[t]{2}{*}{ Leaf } & On & 2.85 & 0.40 & 0.20 & 0.00 & 0.00 & 0.33 & 0.00 & 0.18 & 0.00 & 0.00 & 0.00 & 0.00 \\
\hline & & Off & 0.00 & 0.00 & 0.00 & 0.10 & 0.00 & 0.08 & 0.00 & 0.09 & 0.00 & 0.11 & 0.00 & 0.00 \\
\hline & \multirow[t]{2}{*}{ Node } & On & 1.88 & 0.25 & 0.30 & 0.00 & 0.00 & 0.04 & 0.00 & 0.06 & 0.00 & 0.00 & 0.00 & 0.00 \\
\hline & & Off & 0.00 & 0.00 & 0.00 & 0.00 & 0.00 & 0.00 & 0.03 & 0.00 & 0.00 & 0.00 & 0.34 & 0.00 \\
\hline & \multirow[t]{2}{*}{ Shoot tip } & On & 0.25 & 0.00 & 0.49 & 0.00 & 0.00 & 0.00 & 0.00 & 0.00 & 0.00 & 0.00 & 0.00 & 0.00 \\
\hline & & Off & 0.00 & 0.00 & 0.00 & 0.00 & 0.00 & 0.00 & 0.00 & 0.00 & 0.00 & 0.00 & 0.00 & 0.00 \\
\hline & Fruit & On & 0.00 & 0.00 & 0.00 & 0.00 & 0.00 & 0.00 & 0.00 & 0.00 & 0.00 & 0.00 & 0.43 & 0.58 \\
\hline \multirow[t]{7}{*}{ Gemlik } & \multirow[t]{2}{*}{ Leaf } & On & 0.00 & 0.00 & 0.27 & 0.00 & 0.00 & 0.00 & 0.00 & 0.00 & 0.00 & 0.03 & 0.00 & 0.00 \\
\hline & & Off & 0.00 & 0.02 & 0.00 & 0.14 & 0.13 & 0.00 & 0.00 & 0.00 & 0.00 & 0.22 & 0.00 & 0.00 \\
\hline & \multirow[t]{2}{*}{ Node } & On & 0.07 & 0.00 & 0.00 & 0.08 & 0.06 & 0.08 & 0.00 & 0.00 & 0.00 & 0.00 & 0.00 & 0.00 \\
\hline & & Off & 0.00 & 0.00 & 0.00 & 0.00 & 0.07 & 0.09 & 0.07 & 0.00 & 0.00 & 0.00 & 0.00 & 0.00 \\
\hline & \multirow[t]{2}{*}{ Shoot tip } & On & 0.05 & 0.53 & 0.00 & 0.00 & 0.00 & 0.00 & 0.00 & 0.00 & 0.00 & 0.00 & 0.00 & 0.00 \\
\hline & & Off & 0.00 & 0.00 & 0.00 & 0.00 & 0.00 & 0.00 & 0.00 & 0.00 & 0.00 & 0.00 & 0.00 & 0.00 \\
\hline & Fruit & On & 0.17 & 0.00 & 0.00 & 0.00 & 0.00 & 0.00 & 0.00 & 0.00 & 0.00 & 0.00 & 0.00 & 0.00 \\
\hline
\end{tabular}

and December in the "on" year. However, 'Memecik' shoot tips interestingly showed IAA peaks in July and August with 1.6 and $0.22 \mu \mathrm{g} \cdot \mathrm{g}^{-1}$, respectively, in the "off" year (Table 4).

The first harvest typically begins around 1 Nov., 8 Nov., and 1 Dec. and lasts until 22 Nov., 30 Nov., and 30 Dec. for 'Gemlik', 'Tavsan Yuregi', and 'Memecik', respectively. $\mathrm{ABA}, \mathrm{GA}_{3}$-like, and kinetin-like hormone concentrations in November prior to the "on" year were highest in 'Memecik' and followed by 'Gemlik' and 'Tavsan Yuregi'. GA Glike $^{-}$ content was undetectable in 'Tavsan Yuregi', while the level was about the same in both "on" and "off" year in 'Gemlik'. ABA and kinetin-like cytokinin levels in the "off" year were lower than in the "on" year in all three cultivars during the initiation period in No- vember. The greatest bloom and fruit-set was found in 'Memecik', followed by 'Gemlik' and 'Tavsan Yuregi'.

These data indicated that high concentrations of phytohormones, especially $\mathrm{GA}_{3}$-like substances during the initiation period, promoted vegetative bud formation, while lower concentrations favored flower bud formation. Lower levels of GA-like substances and slightly higher levels of ABA favored flower bud formation during the fall initiation period. Chen (1987) reported similar results in mango.

Several studies evaluated exogenous applications of growth regulators to improve olive yield in the "off" year (Akillioglu, 1991; Eris and Barut, 1991; Lavee et al., 1983; Sibbett and Martin, 1981; Usanmaz, 1974). However, no commercial recommendation has been adapted from these studies. GA-like substances and
IAA concentrations were found to be higher in the "off" year, while levels of kinetin-like substances were found to be essentially the same in both "on" and "off" years during bloom (May). Low levels of GA-like and high levels of ABA were associated with blooming and fruit setting.

As indicated by Ferguson et al. (1994), phytohormones have a triggering effect on the initiation of vegetative and flower buds on the new shoot growth of olives. Levels of endogenous phytohormones in July, November, January, and March were found to be critical for flower bud induction and development. If endogenous hormone levels are high during these months, vegetative bud formation is induced, while low levels promote flower bud formation. The GA-like concentrations and GA : ABA ratio from November to January 
appear to have an effect on flower bud formation. High levels of GA in July previous to the "off" years promoted vigorous shoot growth and reduced flower bud formation. If ABA levels were found to be higher than GA levels, flower bud formation was increased during the initiation period. On the other hand, if ABA levels were lower than GA, vegetative bud formation was favored. High GA-like concentrations in apical buds in the "off" year, especially in March during the differentiation period, affected the number of annual shoots. High GA-like concentrations during this time increased annual shoot formation, whereas low concentrations decreased shoot numbers. These data indicate a general interrelationship between plant hormone concentrations and alternate bearing in olives.

\section{Literature Cited}

Agricultural Structure and Production (ASP). 1996. Publ. No. 2097. D and E Publ., Ankara, Turkey.
Akillioglu, M. 1991. The use of plant growth regulators and the control of alternate bearing in olive, p. 2. Olea abstr. 21.

Chen, W.S. 1987. Endogenous growth substances in relation to shoot growth and flower bud development of mango. J. Amer. Soc. Hort. Sci. 112:360-363.

Dokuzoguz, G. and K. Mendilcioglu. 1976. Zeytin. Ege Univ. Ziraat Fakültesi Yayinlari, Bornova, Zmir. p. 10-18.

Epstein, E. 1981. Concentration of free and bound indole-3-acetic acid (IAA) in leaves of fruit-bearing and barren olive and citrus. Plant Physiol. 67(Suppl.)4.

Eris, A. and E. Barut. 1991. Growth regulators used for decreasing the severity of alternate bearing in olive, p. 11. Olea abstr. 21.

Ferguson, L., G.S. Sibbett, and G.C. Martin. 1994. Olive production manual. Univ. Calif. Div. Agr. Nat. Resour. Publ. 3353.

Hagazi, E.S. and G.R. Stino. 1985. Chemical regulation of sex expression in certain olive cultivars. Hort. Abstr. 55(11):9064.

Hartmann, H.T. 1953. Effects of winter-chilling on fruitfulness and vegetative growth in the olive. Proc. Amer. Soc. Hort. Sci. 62:184-190.
Hartmann, H.T., M.S. Fadl, and W.P. Hackett. 1967. Initiation of flowering and changes in endogenous inhibitors and promoters in olive buds as a result of chilling. Physiol. Plant. 20:746-759.

Lavee. S. 1985. Olea europea, p. 423-434. In: A. $\mathrm{H}$. Halevy (ed.). CRC handbook of flowering. CRC Press, Boca Raton, Fla.

Lavee. S. 1986. Olive, p. 261-276. In: S.P. Monselise (ed.). CRC handbook of fruit set and development. CRC Press, Boca Raton, Fla.

Lavee S., Y. Ben-Tal, I. Klein, and E. Epstein. 1983. Regulation of fruiting in olives. Inst. Hort. Agr. Res. Org., The Volcani Center, Publ. 222.

Palese, A.M. and S.J. Crocker. 2002. Preliminary investigations of endogenous gibberellins in seeds of olive fruits. Acta Hort. 586:525-528.

Rivier, L. and A. Crozier. 1987. Principles and practice of plant hormone analysis. vols. 1 and 2. Academic Press, New York.

Shulman, Y. and S. Lavee. 1976. Endogenous cytokinins in maturing Manzanillo olive fruits. Plant Physiol. 57:490-492.

Shulman, Y. and S. Lavee. 1980. Gibberellin-like substances during ripening of olive fruit. Sci. Hort. 12:169-175. 